\title{
SLIDING DOORS IN BRUSSELS: A CAREER PATH ANALYSIS OF EU AFFAIRS MANAGERS
}

\section{DAVID COEN \& MATIA VANNONI}

School of Public Policy, University College London (UCL), UK

\begin{abstract}
In this paper we investigate the revolving doors phenomenon in the EU. In so doing, we propose a management approach which treats this phenomenon as a form of corporate political activity through which companies try to gain access to decision-makers. By using sequence analysis to examine the career paths of almost $300 \mathrm{EU}$ affairs managers based in public and private companies across 26 countries, we identify three different ideal-typical managers: those EU affairs managers coming from EU institutions and public affairs, those who make a career through the private sector and those who establish themselves in national political institutions. This identification confirms our claim that EU institutions need different types of information and companies need EU affairs managers with different professional backgrounds able to provide it. Rather than observing a revolving door of EU officials into EU government affairs, we observe what we call sliding doors, namely the separation of careers, especially between the public and private sectors.
\end{abstract}

Keywords: Corporate Political Activity; EU Lobbying; Revolving Doors; Public Affairs; Business and Government 


\section{Introduction}

In the US, the contemporary phenomenon of revolving doors represents the legacy of the public role businessmen and entrepreneurs have played since the New Deal. This phenomenon has been recognized and studied since the 1980 s, chiefly from a political economy perspective. The focus of the analysis has been on the individual incentives of the manager/regulator to enter revolving doors and their macro effects, such as regulatory capture. Yet little is said on the business side and the mechanisms underlying the incentives of firms to hire managers with experience in the private sectors have been overlooked.

In this work we propose a management approach to revolving doors by treating this phenomenon not as something unique but as a form of corporate political activity. Companies act in the political arena by exchanging resources with the public authorities for access to the decisionmaking process. Recent American works on revolving doors suggest that managers with experience in the public sector provide firms with personal contacts, which in turn allow firms' improved access to decision-makers. The political currency in the EU is, instead, information; companies need to provide EU institutions with different types of information. More specifically, EU institutions need information on European and national interests as well as expert knowledge. We investigate the choice of who is hired as public affairs manager within a firm through these theoretical lenses. We posit that different professional backgrounds of a manager increase the capability of the firm to provide different types of information. In this vein, we expect to see more variation in terms of career paths with respect to the US, and less revolving doors.

Drawing on a sequence analysis of an original data set collected mainly from LinkedIn of almost 300 EU affairs managers' career paths across 26 countries, we find out that managers have three 
types of professional background: private sector, national political sector and EU institutions and public affairs. This is in line with expectations from our management approach to revolving doors, which suggest that as EU institutions need different types of information, companies are incentivised to hire managers with different professional backgrounds. Significantly, we show that personnel exchange between EU institutions and business is rarer than revolving doors discussions would lead us to believe and that EU affairs managers' careers are rather static and that there is a neat separation between private and public careers. As such, we see the public affairs process in the EU as more a sliding doors phenomenon than a Brussels-based one of revolving doors involving European experts from EU institutions and satellite European organizations and associations.

\section{A Political Economy Approach to Revolving Doors}

In the US, business has consistently played a public role, similar to other developed countries (Vogel 1978). This public role has taken place mainly at an individual level, with a tradition of businessmen sitting in key government positions inaugurated with the New Deal (Vogel 1996a; Vogel 1996b; Vogel 1978). Until the 1960s, this phenomenon was more circumscribed, confined to the very high ranks of business and government (Vogel 1978). But in the 1970s, the increase in the competences of the federal government (Vogel 1996a; Vogel 1996b; Hillman et al. 1999) and the professionalization of corporate political activity (Vogel 1978; Yoffie \& Bergenstein 1985; Martin 1994) widened the scope of this phenomenon. Managers with legal, public relations and first-hand government experience started to enter major companies at all levels (Yoffie \& Bergenstein 1985). Since then, personnel exchange between the public and the private sector has been a predominant feature of business-government relations in the US, receiving formal recognition with the label 'revolving doors'. Currently, half of the lobbyists in 
Washington have working experience in the federal government (LaPira \& Thomas 2014). This is confirmed by other works. Lazarus et al. (2016) find that in the US from 1976 to 2012 a quarter and almost a third of respectively House members and senators became lobbyists, with this trend increasing over time. Finally, Cain \& Drutman (2014) demonstrate that roughly a fifth of staff leaving the Congress became lobbyists.

Presumably because it has always been considered congenital to the capitalist state in the US, the phenomenon of revolving doors only started to be studied in a consistent manner in the 1980s, mainly from a political economy perspective. Studies of revolving doors have focused on how individual incentives affect regulatory behaviour. These works identify two types of revolving doors dynamics: ex ante and ex post (Gormley 1979; Dal Bo 2006) ${ }^{1}$. Despite the different underlying dynamics, these forms of revolving doors elicit the same consequence on regulatory behaviour: regulatory capture. In other words, regulators with prospective or previous experience in a regulated sector tend to be more supportive of that sector.

The prospect of working for the private sector alters the willingness to pursue the objectives of the government against those of the firm (Che 1995). The incentives at stake are mainly monetary (Quirk 1981; Adams 1982). As emphasized in one of the most important works in this field: "It is documented that regulators with five years' public service can triple their salaries just by stepping out the revolving door" (Newsweek, 1989, in Che, 1995 p. 393). This has been empirically demonstrated in more recent studies (Blanes i Vidal et al. 2012; Cain \& Drutman 2014). Previous work experience in the private sector elicits the same consequence (Gormley 1979). The dynamics at play span from the hard core logrolling proposed by traditional political science literature to the softer versions proposed by socialization and elite background theories (Mills 1961; Domhoff 1967; Miliband 1969; Putnam 1976; Navarro 1982; Zingales 2012). 
Findings show that revolving doors in both forms lead to a positive attitude of regulators towards the regulated industry. The two most cited empirical analyses of this process, Gormley (1979) and Cohen (1986), investigate the impact of revolving doors on voting behaviour in the US Federal Communications Commission (FCC). Both find that regulators with previous experience in the private sector tend to be more in favour of the industry at the beginning of their terms with the reverse true for those with future experience in the private sector. The very same dynamics have been demonstrated to also take place in public administrations (Trondal et al. 2015). Recent works from a more interest group politics perspective confirm that hiring covered officials (the official definition of revolving doors lobbyists in the US) is associated with favourable regulation (Baumgartner et al. 2009; Lazarus \& McKay 2012).

\section{A Management Approach to Revolving Doors}

Recent works on revolving doors in the US suggest that companies hire individuals with experience in the public sector not because of their expertise but because of their personal contacts (Bertrand et al. 2011; Blanes i Vidal et al. 2012; Cain \& Drutman 2014; LaPira \& Thomas 2014; Lazarus et al. 2016). We build on this new perspective for the management approach to revolving doors proposed in this work. The management literature focuses on why business acts in the political arena, how it does so and what explains its behaviour (Getz 2001). Among the several perspectives on CPA, the resource dependence theory, founded on the resource-based view of the firm in business studies and organizational theories in sociology, is the most commonly used approach (Getz 2001; McWilliams et al. 2002; Hillman et al. 2004). The main argument is that firms act in the political arena because they need something from the public authority, which may be access to the decision-making process or direct revenues. In so doing, they exchange resources with the public authority. 
We apply this management perspective in order to shed light on the revolving doors dynamics at play in the EU. In the US companies hire managers with experience in the private sector because they provide something which is crucial for the company to gain access to the government: personal contacts. Yet in the EU the political currency is not personal contacts but information (Eising 2007). By building on a resource dependence perspective, the mainstream approach to EU (corporate) lobbying, namely the theory of access, suggests that companies adopt different strategies in order to exchange different types information with EU institutions.

The theory of access (Bouwen 2002; Bouwen 2004; Eising 2007) studies the interaction between the demand side, namely European institutions, and the supply side, namely companies, from a resource dependence perspective. Companies provide decision-makers with information in exchange for access (Bouwen 2002; Bouwen 2004). The venue and degree of access is determined mainly by the goodness of fit between the resources provided by companies and the institutional opportunities (Eising 2007). The latter in turn derive from the internal arrangements and competences of European institutions. Several other studies confirm the centrality of information provision in the EU lobbying system (Chalmers 2011; Klüver 2012).

Bouwen (2002) demonstrates that, to differing degrees, European institutions need three types of information: domestic encompassing interest, European encompassing interest, and, expert knowledge (Bouwen 2002; Bouwen 2004). Business provides these types of information by using different strategies. Direct action is associated with the provision of expert knowledge, whereas collective action at national and European level provides, respectively, information on domestic encompassing and European encompassing information. 
We conceive the creation of a public affairs role in the firm and who is appointed therein as a form of CPA and, as such, we investigate it from a resource dependence perspective. The creation of a public affairs role specifically in charge of the relationship with the EU represents the first step to convey certain information to EU institutions. Furthermore, the choice of appointment to that role can also be seen in this light. In line with the theory of access, we posit that individuals from specific backgrounds can substantially increase the capability of a firm to provide specific types of information. An official with working experience in the EU institutions increases the capability of a firm to provide information about the European encompassing interest, whereas an official coming from national authorities can provide the firm with information capability with respect to domestic encompassing interest. Finally, experience in the private sector can arguably be associated with the provision of expert knowledge.

This new perspective leads to expectations on revolving doors in the EU which differ from those suggested by media headlines and from what happens on the other side of the Atlantic. We expect to observe limited levels of revolving doors in the EU. In fact, for companies, different types of information represent valuable resources to be exchanged for access to the decisionmaking process and only some of them are associated with working experience in EU institutions. Companies also need information on interests at domestic level and expert knowledge to access the European decision-making process. Accordingly, we expect firms to hire managers with working experience in EU institutions but also managers with experience in the private sector and in national authorities.

This management approach to revolving doors elicits two main implications: the normalization of the phenomenon of revolving doors and the cross-fertilization between the American management and EU lobbying scholarships. First, this study emphasizes the importance of 
studying this phenomenon by treating it as a form of CPA and not as something unique. The management literature itself has recently emphasized the necessity to expand the study of CPA to forms other than the conventional ones (Hillman et al. 2004; Lawton et al. 2013). Second, EU lobbying scholars have mainly focused on the action of the firm in terms of access to European institutions (Bouwen 2002; Broscheid \& Coen 2003; Mahoney 2004; Broscheid \& Coen 2007; Vannoni 2015) and the presence of EU affairs offices (Bernhagen \& Mitchell 2009). By building on one of the mainstream approaches to EU lobbying, this project shifts the focus to management decisions on who within firms actually represents them vis-à-vis the EU.

Before we introduce the unique dataset on which the study relies, two caveats are needed. First, how the institutional differences between the EU and the US shape the individual incentives of the regulator/manager, should not be overlooked. For instance, the permeability of the federal state and the wage differential between public and private sectors in the US increase individual incentives to step into revolving doors. Conversely, EU bureaucrats have permanent contracts with good benefits and usually show a strong sense of belonging to the EU community. This focus on individual incentives can explain why the phenomenon of revolving doors is perhaps more noticeable for those moving from high-ranking but temporary fix term positions, such as Commissioners (CEO 2015). Yet, this perspective can only account for whether and to what extent the phenomenon of revolving doors is present, not for where managers come from. The management approach based on the resource dependence theory used in this work is hence more explanatorily powerful, as it provides a compelling argument on the professional background of public affairs managers which encompasses but goes beyond the revolving doors debate. For instance, this approach accounts also for multi-level revolving doors, namely the personnel exchange between public authorities at difference levels of governance and the private sector. 
Second, this work focuses on in-house public affairs managers, not private lobbyists. It might be argued that revolving doors is in place mainly for the latter, which are not studied in this work. Indeed, recent work in the US finds a significant difference between private and in-house lobbyists: the former are more likely to come from the public sector (LaPira \& Thomas 2014) and the great majority of those who leave the legislature tend to work as private lobbyists as a first job (Lazarus et al. 2016). Yet, it has been demonstrated that the use of consultants and private lobbyists is less common in the EU (Coen 1997; Coen 1998; Kohler-Koch \& Quittkat 1999). Accordingly, if personal contacts also represented important resources in the EU, we would observe the phenomenon of revolving doors for in-house public affairs managers.

\section{Data and Measurement}

The analysis relies on a dataset with all the public and private companies politically active in the EU in the past ten years ${ }^{2}$. Observations are drawn from various sources from different years: the EU Transparency Register (CEC 2014), various semi-public directories (EA 2006; EA 2007; EA 2008b; EA 2008a; DODs 2014) and a dataset from other authors (Wonka et al. 2010). The EU Transparency Register is close in spirit to the lobbying register in the US: it contains up to date information on the interests represented at the EU level and who represents them. Semi-public directories range from those providing information on the interests involved in specific sectors and in different years (EA 2006; EA 2007; EA 2008b; EA 2008a) to those providing up to date information on the companies active in the EU in all sectors (DODs 2014). Finally, the dataset presented in Wonka et al. (2010) gathers information on the interests represented at EU level from a wide array of sources, including previous versions of the directories mentioned above. We cross check observations from all these sources, while dropping doubles and retaining only public and private companies. The result is a dataset of 512 (economically active) public and 
private companies based in 32 countries and 13 sectors, ranging in size from a few employees to hundreds of thousands of people ${ }^{3}$.

We then check whether the companies in the dataset are still active politically in the EU and identify public affairs managers through the 2014 DOD's European Public Affairs Directory (DODs 2014) and the EU Transparency Register (CEC 2014). Those individuals registered as in charge of EU public affairs for the respective company are individuated ${ }^{4}$. Where more individuals are mentioned we check across sources to identify a single one. Information on their professional background is then drawn from professional social networks, such as LinkedIn ${ }^{5}$, as well as from corporate, personal and public affairs/business websites, such as European Agenda and Bloomberg Business. Information is gathered on their current role and their previous occupations. The final dataset contains 325 public affairs managers, 297 of which include information on their professional background.

\section{Research Design}

Although several methods might be used to analyze career data, such as time series analysis, we propose sequence analysis (Blanchard 2005; Brzinsky-Fay et al. 2006; Blanchard 2011; Blanchard et al. 2014). Sequence analysis is compatible with two fundamental aspects of career data: their temporal and categorical aspects. In contrast to the data dealt with by time series analysis, career data are categorical, and most importantly, they are often measured across time points not equally distant from one another. Unlike traditional time series analysis, sequence analysis is compatible with observations measured across relative rather than absolute points in time (Brzinsky-Fay et al. 2006). Originating in labor market sociology (Abbott \& Hrycak 1990; Abbott 1991; Halpin \& Cban 1998; Blair - Loy 1999; Halpin 2007) sequence analysis has only 
very recently started to be applied in political science and more specifically in political elite studies (Blanchard 2005; Tepe \& Marcinkiewicz 2013; Jäckle 2016). Nonetheless, no application of sequence analysis is present in business elite studies.

Sequence analysis is a toolkit comprising data mining, descriptive and statistics tools. In this work we use what is considered to be the standard practice in conducting sequence analysis. We start by illustrating descriptive statistics on the frequencies of elements along the sequences, namely on the occupational background of EU affairs managers across the steps in their career paths. In this way we describe EU affairs managers' career paths and how they evolve across career steps. Then, we calculate the distances across sequences and cluster those distances in order to obtain ideal-typical career paths. Finally, we shift the attention from single states to transitions (between states) within sequences by investigating the most discriminant transitions in each cluster. We do so by using the TraMineR package in R (Gabadinho et al. 2010a; Gabadinho et al. 2010b; Gabadinho et al. 2011; Studer et al. 2011) ${ }^{6}$.

The method used in this work to calculate distances across sequences is called Optimal Matching, which compares sequences on the basis of an algorithm first used in biology (Needleman \& Wunsch 1970). This algorithm compares sequences by pairs of states and calculates a distance index based on the replacement of different elements (Brzinsky-Fay et al. 2006; Blanchard 2011; Blanchard et al. 2014). In other words, it calculates the distance between two sequences as the cost to transform one into the other by considering the insertion/deletion and substitution of elements (Studer et al. 2011). We acknowledge that several methods based on different algorithms are available (Studer et al. 2011), but Optimal Matching represents standard practice in sequence analysis. It is common practice in sequence analysis to proceed by clustering similar sequences into clusters/groups by using the distance matrix calculated with 
Optimal Matching. Although different methods are present, we employ the most common method, hierarchical clustering. By starting from single sequences, the clustering process aggregates them into groups/clusters of similar sequences (i.e. less distant based on the matrix above). The process continues until a definite amount of groups/clusters is obtained. These groups/clusters are the 'ideal-typical' sequences, which show recurrent patterns in the sample (Abbott \& Hrycak 1990; Abbott 1991). Finally, we move the attention from states to transitions. Sequences can be analysed in terms of single states or transitions between single states. In the final part of the analysis we look at those transitions that discriminate significantly the groups/clusters obtained using the method discussed above.

\section{A Career Path Analysis of EU Affairs Managers}

We start by showing descriptive statistics, derived with the TraMineR R package (Gabadinho et al. 2010a; Gabadinho et al. 2011; Studer et al. 2011; Studer 2013), to illustrate the career paths of EU affairs managers. Figure 1 shows the distribution plot of the frequency of each occupation for each step in the career path of EU managers (close in spirit to a traditional stacked bar chart). The horizontal axis shows the various steps in the managers' career paths, from type6, the most distant in time, to typel, the most recent previous occupation. We code the professional background of EU managers according to eight categories: firm (including also previous occupation in the same firm), association, PR/public affairs/law firm/journalist, research center/think tank/NGO, (sub-)national authority, EU institution, other supranational organization and army ${ }^{7}$. 
Figure 1 Sequence Analysis: State Distribution Plot

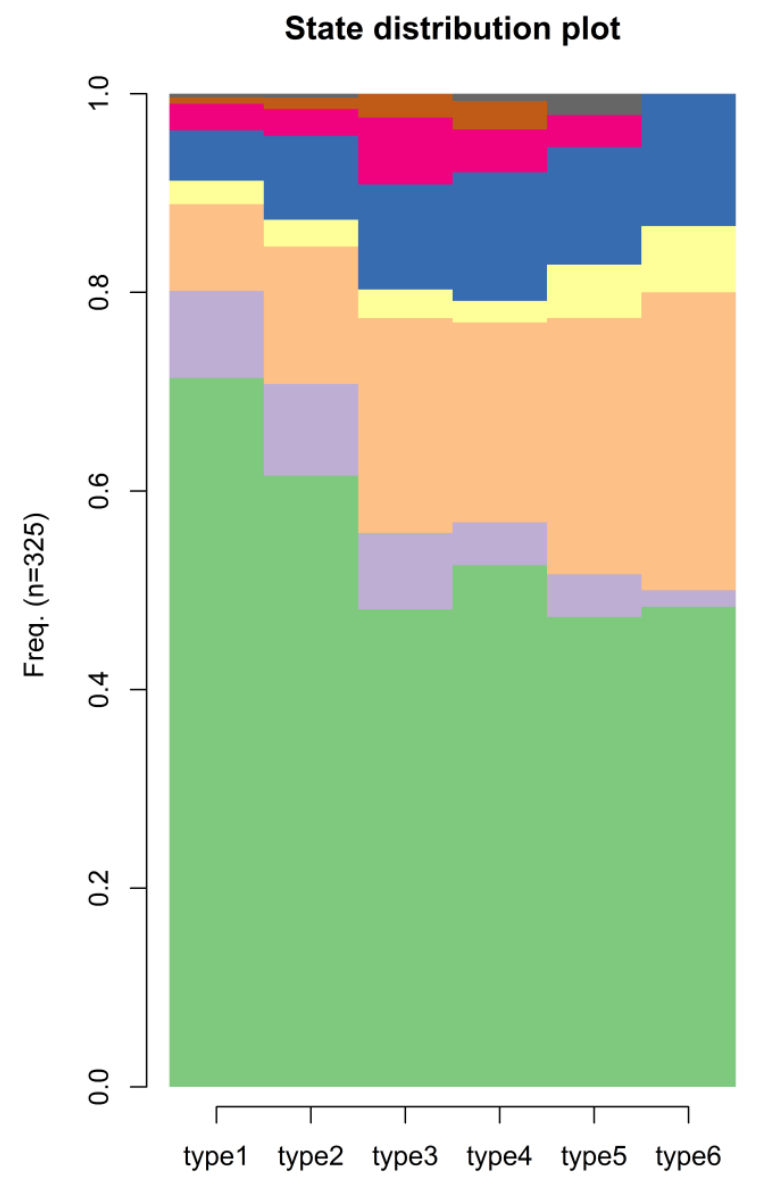

Some preliminary findings can be drawn from Figure 1. First, we can see that the most frequent previous occupation is in the private sector and the second most frequent is in PR/public affairs companies, followed by (sub-)national authorities. Jobs in the private sector account for half of the total at the very beginning, increasing to approximately 70 per cent towards the end of the career path (in type1, namely the most recent previous occupation). This is explained by the fact that several EU affairs managers come from inside the firm, where they have undergone a long career. Indeed, when we disaggregate the firm category into two subcategories, namely same firm against different firm, we see that although at the beginning of the career path the presence 
of experience in other firms is prevalent, over time the presence of experience in the same firm increases until it becomes the most prevalent occupation type. Almost half of the managers in the sample were in the same firm previously. Relatedly, although working experience outside the private sector accounts for half of the managers' professional background at the beginning of their career, it significantly decreases towards the end.

Furthermore, it should be noted that working experience in EU institutions is not predominant. Only 32 managers have working experience in one of the EU institutions; approximately 10 per cent of the sample. This contrasts strongly to the US where roughly half of lobbyists have working experience in the public sector at federal level (LaPira \& Thomas 2014). Furthermore, working experience in the EU is rather distant in time from the current job, suggesting that even when the phenomenon of revolving doors is in place EU officials are not parachuted into EU affairs offices within companies. This, again, is in stark contrast with the US where revolving door lobbyists start to work for the private sector in either the same year they leave or during the following one (Lazarus et al. 2016). This is further discussed below where we focus on how frequently the direct transition from the public to the private sector (and vice versa) occurs in the sample.

What comes out from Figure 1 is that EU affairs managers start their careers in the private sector or in PR and public affairs agencies and then gain (more) experience in the private sector. They have to climb the ladder inside the firm. This is also confirmed by the fact that on average the managers in the sample have spent six years in their current positions, with some having stayed there for more than 15 years. Hence, while their initial background is rather variegated, 
managers' experience becomes more common with time. Despite some experience in PR and public affairs as well as in national authorities, EU affairs managers have careers which are not so different from other middle level managers.

We proceed to investigate the empirically observable implications of the arguments put forward above. By conceiving revolving doors within a broader management approach to CPA we posit above that EU affairs managers provide firms with resources indispensable to gaining access to the decision-making system. As put forward by the theory of access, in the EU the most valuable resources for firms are information about European and domestic interests along with expert knowledge. We argue that the working experience of managers in the EU, national authorities and the private sector is associated with the provision of these types of information. In this vein, we expect to observe three ideal-typical career paths across EU affairs managers: the first comprises mostly of experience in the private sector, the second comprises mostly of experience in national authorities and the third experience in EU institutions.

We calculate the distance matrix between sequences and by clustering it we obtain representative sequences. The results of the clustering process are shown in Figure 2. We find three idealtypical career paths ${ }^{8}$. Managers falling into the first group have, in relative terms, more experience in national authorities. Interestingly, we observe that working experience in European institutions and PR/public affairs is clustered together in the second group. Significantly, this means that those managers with experience in European institutions also tend to have experience in PR and public affairs. The third group contains managers with high experience in the private sector. 
Figure 2 Sequence Analysis: State Distribution Plots of the Clusters
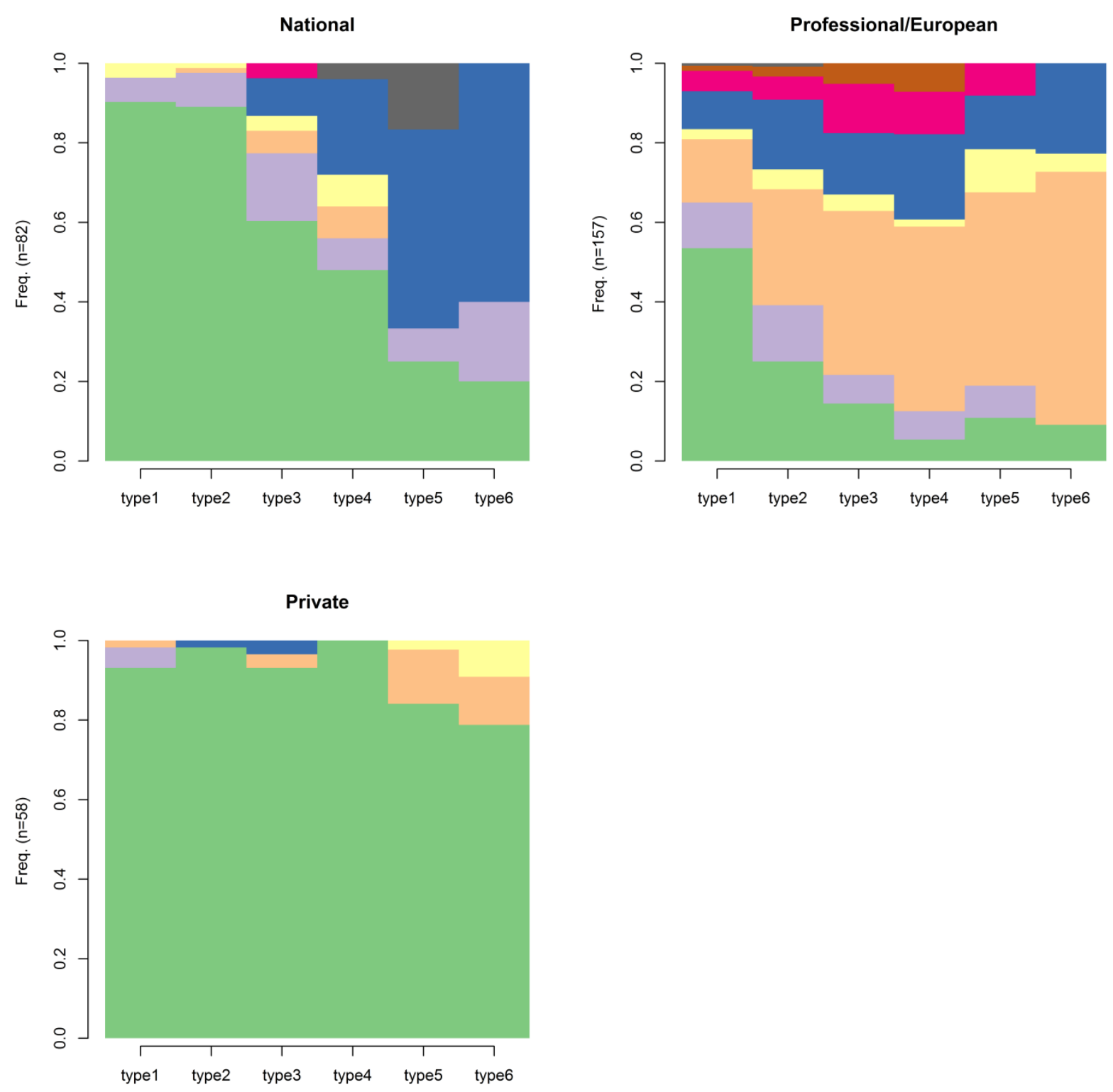

We find empirical evidence for the presence of the three ideal-typical EU affairs managers hypothesized above. The first one has experience mainly at national level, either in national or subnational government: we label this National. The second ideal-typical EU manager is more European and public affairs professional: he or she has experience in EU institutions and/or in PR companies and hence we call this European/Professional. Finally, the third ideal-typical 
manager is a manager with experience in the private sector, especially in his/her own firm: we label this Private. In conclusion, we find empirical evidence which supports the claims put forward above. The three representative career paths obtained through clustering are those suggested by the management approach to revolving doors presented above.

A few remarks are needed. Firstly, working experience in PR/public affairs companies is rather common and is clustered with working experience in EU institutions. This suggests that information on European encompassing interests can be obtained either through working experience in EU institutions or in public affairs companies working in the EU. Presumably, given the disincentives to move from the public to the private sector in the EU underlined above, individuals become expert in the EU public policy process indirectly, namely by working for public affairs companies which work on EU affairs instead of in EU institutions themselves.

Secondly, it should be noted that common trends are present across career paths. For instance, the presence of working experience in the private sector increases as we get closer to the final position in the government affairs office. This means that, in general, EU managers need to have experience in a private working environment and more specifically in their own firms before graduating to the senior posts in EU government affairs. This disconfirms the common perception in Brussels that public affairs managers are parachuted into firms.

We proceed by investigating the most discriminating transitions (and states) between clusters. Findings in Figure 3 provide further confirmation for our claims. First of all, we find that the most frequent transitions we expect to take place across career paths according to our claims 
vary in a statistically significant manner across clusters and do so in accordance to our theory. One of the transition of interest, namely from Firm to PR/Public Affairs, is positively correlated with the group European/Professional and negatively with the group National. This also holds true for single states. As can be seen, the presence of the state Firm is positively associated with Private but negatively with European/Professional. The presence of the state PR/public affairs is positively associated with European/Professional and negatively with Private. In conclusion, it should be noted how sequences are strongly clustered into the three groups theorized, both in terms of single states and transitions. Contradicting the common belief, career paths in Brussels are rather static and a neat separation between them is present. 
Figure 3 Sequence Analysis: Discriminating Transitions across Clusters

National

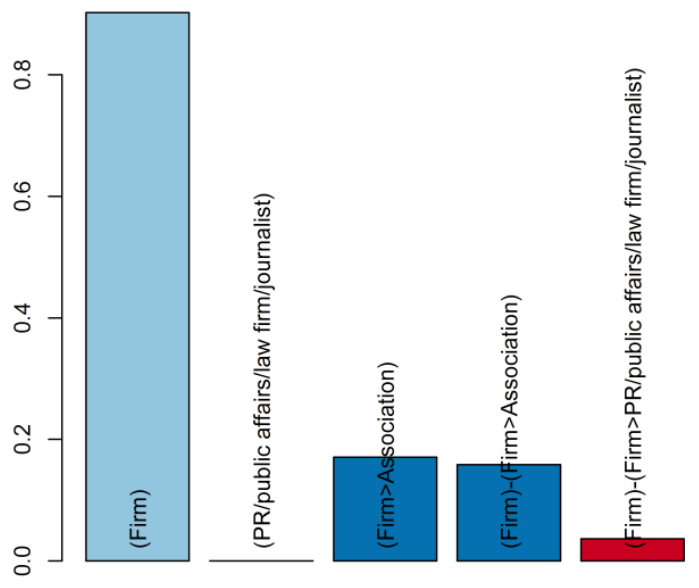

Professional/European

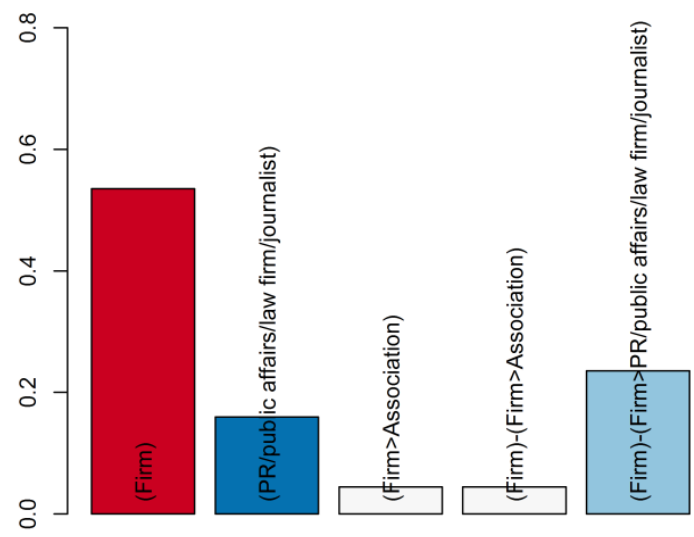

Color by sign and significance of Pearson's residual

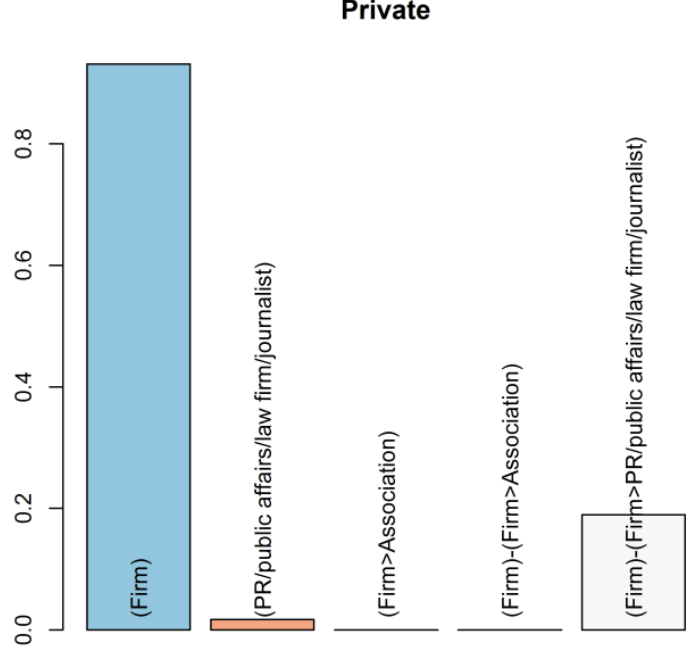

口 Negative 0.01

$\square$ Negative 0.05

$\square$ neutral

$\square$ Positive 0.05
$\square \quad$ Positive 0.01

The focus on transitions is particularly interesting in testing the revolving doors argument. We calculate the frequency of transitions from Firm to EU Institution and from EU Institution to Firm in the dataset. The former appears once, whereas the latter appears nine times: in total the direct exchange of personnel between EU institutions and firms occurs only 10 times in the dataset. The second transition containing EU institutions is with PR/Public affairs, which appears 
nine times in total. This provides further evidence for the limited exchange of personnel between EU institutions and business and for the finding above that working experience in public affairs companies is a 'surrogate' for working experience in EU institutions.

The low presence of exchange of personnel between business and EU institutions calls into question the revolving doors phenomenon in the EU. Several leading media commentators and NGOs lament the unregulated flow of staff between major companies and EU institutions. We find that this is not the case for managers in EU affairs offices. Rather, our findings suggest a more complex picture of career paths in EU affairs and we put forward the concept of sliding doors ${ }^{9}$. This term goes beyond referring to the very low personnel exchange between the EU and business, a fact which is interesting in itself. Sliding doors point to the static character of managers' careers. Indeed, as seen above, just three career paths represent more than two thirds of the managers in the sample and the division between them is rather neat. For instance, the chances of moving from a PR/public affairs company or EU institutions to certain firms are very low: there is a neat separation between careers in Brussels and especially between public and private ones. The reason lies in the specialization of managers: some of them focus on the EU public policy process, whereas others on the national one. Others again specialize in expert knowledge of the core competences of the firm/industry in which they work. Different working experiences are associated with different skills which require years to acquire and which represent valuable resources for companies. This aspect can only be accounted for by a broader approach to revolving doors, such as the management one proposed in this work. 


\section{Conclusion}

Washington is always depicted as a grey area of people going back and forth between business and governmental bodies: the term revolving doors entered the political dictionary many decades ago. We demonstrate that this is not the case in Brussels, as there is a neat separation between careers and especially between those in the public and in the private sectors: we put forward the concept of sliding doors to account for this phenomenon.

The management approach used in this work suggests that in the US managers with experience in the private sector bring their personal contacts to the firm, which they then use to gain access to the decision-making process. In the EU, the political currency is information, namely what you know and not who you know. Managers specialize in the provision of different types of information, which are extremely valuable resources for companies. Since EU institutions demand different types of information, there are incentives for companies to hire managers with different professional experiences, which is why we observe more variation across career paths and less revolving doors in Brussels. Furthermore, this process of specialization of managers in the provision of certain information takes years. As such, strong individual disincentives are present to change career path which explains the static nature of EU affairs managers' career paths. This forms the basis of what we call sliding doors.

Not only does this work provide the first large $\mathrm{N}$ study on revolving doors in the EU, hence suggesting a completely new research agenda, it also speaks to different scholarships. Although the term revolving doors has entered the political debate at EU level within the last few years, little if any academic attention has been paid to this phenomenon. In this work, we suggest a new research agenda to understand the different varieties of business and government relations at 
micro level and the different types of doors between the public and the private sectors which may emerge. Finally, the approach used in this work treats the phenomenon of revolving doors as a form of corporate political activity and as such we analyse it from a resource dependence perspective. The latter has been used extensively in both American management and European interest group politics literature and this work aims to encourage more cross-fertilization between these two scholarships.

\section{Acknowledgements}

We acknowledge financial support from the British Academy (BA/Leverhulme Small Research Grant number 522590). Furthermore, we are grateful to three anonymous EJPR reviewers for insightful comments.

\section{Supporting Information}

Additional Supporting Information may be found in the online version of this article at the publisher's web-site:

Web-Appendix: Table 1 Frequency Table 


\section{Web-Appendix}

Table 1 Frequency Table

\begin{tabular}{|c|c|c|c|c|c|c|}
\hline & type1 & type2 & type3 & type4 & type5 & type6 \\
\hline Firm & 0.7138 & 0.6154 & 0.481 & 0.5252 & 0.473 & 0.483 \\
\hline Association & 0.0875 & 0.0923 & 0.077 & 0.0432 & 0.043 & 0.017 \\
\hline $\begin{array}{l}\mathrm{PR} / \text { public } \\
\text { affairs/law } \\
\text { firm/journalist }\end{array}$ & 0.0875 & 0.1385 & 0.216 & 0.2014 & 0.258 & 0.300 \\
\hline $\begin{array}{l}\text { Research } \\
\text { center/think } \\
\text { tank/NGO }\end{array}$ & 0.0236 & 0.0269 & 0.029 & 0.0216 & 0.054 & 0.067 \\
\hline $\begin{array}{l}\text { (Sub- } \\
\text { )National } \\
\text { Authority }\end{array}$ & 0.0505 & 0.0846 & 0.106 & 0.1295 & 0.118 & 0.133 \\
\hline EU Institution & 0.0269 & 0.0269 & 0.067 & 0.0432 & 0.032 & 0.000 \\
\hline $\begin{array}{l}\text { Other } \\
\text { Supranational } \\
\text { Organization } \\
\end{array}$ & 0.0067 & 0.0115 & 0.024 & 0.0288 & 0.000 & 0.000 \\
\hline Army & 0.0034 & 0.0038 & 0.000 & 0.0072 & 0.022 & 0.000 \\
\hline TOT & 297 & 260 & 208 & 139 & 93 & 60 \\
\hline
\end{tabular}




\section{References}

Abbott, A. (1991). The order of professionalization: An empirical analysis. Work and Occupations 18(4): 355-384.

Abbott, A. \& Hrycak, A. (1990). Measuring resemblance in sequence data: An optimal matching analysis of musicians' careers. American Journal of Sociology 96(1): 144-185.

Adams, G. (1982). Politics of defense contracting. New Brunswick, NJ: Transactions Publishers.

Barron, A. (2011). The impact of national business cultures on large firm lobbying in the european union: Evidence from a large-scale survey of government affairs managers. Journal of European Integration 33(4): 487-505.

Baumgartner, F. R. ,Berry, J. M. ,Hojnacki, M. ,Leech, B. L. \& Kimball, D. C. (2009). Lobbying and policy change: Who wins, who loses, and why. Chicago, IL: University of Chicago Press.

Bernhagen, P. \& Mitchell, N. J. (2009). The determinants of direct corporate lobbying in the European Union. European Union Politics 10(2): 155-176.

Bertrand, M. ,Bombardini, M. \& Trebbi, F. (2011). Is it whom you know or what you know? An empirical assessment of the lobbying process. National Bureau of Economic Research Working Papers 16765.

Blair-Loy, M. (1999). Career patterns of executive women in finance: An optimal matching analysis. American Journal of Sociology 104(5): 1346-1397.

Blanchard, P. (2005). Multidimensional biographies. Explaining disengagement through sequence analysis. Paper presented at ECPR General Conference.

Blanchard, P. (2011). Sequence analysis for political science. Paper presented at APSA Conference

Blanchard, P. ,Bühlmann, F. \& Gauthier, J.-A. (2014). Advances in sequence analysis: Theory, method, applications. New York, NY: Springer.

Blanes i Vidal, J. ,Draca, M. \& Fons-Rosen, C. (2012). Revolving door lobbyists. The American Economic Review 102(7): 3731-3748.

Bouwen, P. (2002). Corporate lobbying in the European Union: The logic of access. Journal of European Public Policy 9(3): 365-390.

Bouwen, P. (2004). Exchanging access goods for access: A comparative study of business lobbying in the European Union institutions. European Journal of Political Research 43(3): 337-369.

Broscheid, A. \& Coen, D. (2003). Insider and outsider lobbying of the European Commission: An informational model of forum politics. European Union Politics 4(2): 165-189.

Broscheid, A. \& Coen, D. (2007). Lobbying activity and fora creation in the EU: Empirically exploring the nature of the policy good. Journal of European Public Policy 14(3): 346365.

Brzinsky-Fay, C. ,Kohler, U. \& Luniak, M. (2006). Sequence analysis with Stata. The Stata Journal 6(4): 435-460.

BureauVanDijk (2014). Amadeus. accessed January 2014 at https://amadeus.bvdinfo.com/version-2016419/home.serv?product=amadeusneo.

Cain, B. \& Drutman, L. (2014). Congressional staff and the revolving door: The impact of regulatory change. Election Law Journal: Rules, Politics, and Policy 13(1): 27-44.

CEC (2014). Transparency Register accessed June 2014 at http://ec.europa.eu/transparencyregister/info/homePage.do. 
CEO (2015). The revolving doors spin again. Barroso II Commissioners join the corporate sector. Corporate Europe Observatory, 28 October 2015. http://corporateeurope.org/revolving-doors/2015/10/revolving-doors-spin-again.

Chalmers, A. W. (2011). Interests, influence and information: Comparing the influence of interest groups in the European Union. Journal of European Integration 33(4): 471-486.

Che, Y.-K. (1995). Revolving doors and the optimal tolerance for agency collusion. The Rand journal of economics 26(3): 378-397.

Coen, D. (1997). The evolution of the large firm as a political actor in the European Union. Journal of European Public Policy 4(1): 91-108.

Coen, D. (1998). The European business interest and the nation state: Large-firm lobbying in the European Union and member states. Journal of Public Policy 18(01): 75-100.

Cohen, J. E. (1986). The dynamics of the "revolving door" on the FCC. American Journal of Political Science 30(4): 689-708.

Dal Bo, E. (2006). Regulatory capture: A review. Oxford Review of Economic Policy 22(2): 203225.

DODs (2014). European Union and public affairs directory: 2014 : The essential guide to the institutions and public affairs community in Brussels. London: Dod's Parliamentary Communications.

Domhoff, G. W. (1967). The power elite and the state: How policy is made in America. Piscataway, NJ: Transaction Publishers.

EA (2006). 75 energy associations, companies, consultancies and institutions. Brussels: Helios Media sprl.

EA (2007). 180 company representations in brussels. Brussels: Helios Media sprl.

EA (2008a). 93 transport associations, companies and institutions. Brussels: Helios Media sprl.

EA (2008b). 156 IT and telecommunication associations, companies and institutions. Brussels: Helios Media sprl.

Eising, R. (2007). Institutional context, organizational resources and strategic choices explaining interest group access in the European Union. European Union Politics 8(3): 329-362.

Gabadinho, A. ,G. Ritschard, and, M. S. \& Muller, N. S. (2010a). Mining sequence data in $R$ with the Traminer package: A user's guide. Geneva: University of Geneva.

Gabadinho, A. ,Ritschard, G. ,Mueller, N. S. \& Studer, M. (2011). Analyzing and visualizing state sequences in R with Traminer. Journal of Statistical Software 40(4): 1-37.

Gabadinho, A. ,Studer, M. ,Ritschard, G. \& Muller, N. S. (2010b). Sequence analysis for social scientists. Introduction to sequence analysis. Paper presented at Summer School on Advanced Methods for the Analysis of Complex Event History Data.

Getz, K. (1993). Selecting corporate political tactics. In Mitnick, B. (ed.) Corporate political agency. Newbury Park, CA: Sage.

Getz, K. A. (2001). Public affairs and political strategy: Theoretical foundations. Journal of Public Affairs 1(4): 305-329.

Gormley, W. T. (1979). A test of the revolving door hypothesis at the FCC. American Journal of Political Science 23(4): 665-683.

Halpin, B. (2007). Sequence analysis. Paper presented at Essex Summer School.

Halpin, B. \& Cban, T. W. (1998). Class careers as sequences: An optimal matching analysis of work-life histories. European Sociological Review 14(2): 111-130.

Hillman, A. J. ,Keim, G. D. \& Schuler, D. (2004). Corporate political activity: A review and research agenda. Journal of Management 30(6): 837-857. 
Hillman, A. J. ,Zardkoohi, A. \& Bierman, L. (1999). Corporate political strategies and firm performance: Indications of firm-specific benefits from personal service in the U.S. Government. Strategic Management Journal 20(1): 67-81.

Jäckle, S. (2016). Pathways to Karlsruhe: A sequence analysis of the careers of German federal constitutional court judges. German Politics 25(1): 25-53.

Klüver, H. (2012). Informational lobbying in the European Union: The effect of organisational characteristics. West European Politics 35(3): 491-510.

Kohler-Koch, B. \& Quittkat, C. (1999). Intermediation of interests in the European Union. Arbeitspapiere - Mannheimer Zentrum für Europäische Sozialforschung Mannheim 9.

LaPira, T. M. \& Thomas, H. F. (2014). Revolving door lobbyists and interest representation. IGA $3(1): 4-29$.

Lawton, T. ,McGuire, S. \& Rajwani, T. (2013). Corporate political activity: A literature review and research agenda. International Journal of Management Reviews 15(1): 86-105.

Lazarus, J. ,McKay, A. \& Herbel, L. (2016). Who walks through the revolving door? Examining the lobbying activity of former members of Congress. IGA 5(1): 82-100.

Lazarus, J. \& McKay, A. M. (2012) Consequences of the revolving door: Evaluating the lobbying success of former congressional members and staff. MPSA conference.

Maddox, H. W. J. (2004). Opportunity costs and outside careers in U.S. State legislatures. Legislative Studies Quarterly 29(4): 517-544.

Mahoney, C. (2004). The power of institutions: State and interest group activity in the European Union. European Union Politics 5(4): 441-466.

Martin, C. J. (1994). Business and the new economic activism: The growth of corporate lobbies in the sixties. Polity 27(1): 49-76.

McWilliams, A. ,Van Fleet, D. D. \& Cory, K. D. (2002). Raising rivals' costs through political strategy: An extension of resource-based theory. Journal of Management Studies 39(5): $707-724$.

Miliband, R. (1969). The state in capitalist society. London: Weidenfeld \& Nicolson.

Mills, C. W. (1961). The power elite. New York, NY: Oxford University Press.

Navarro, P. (1982). Public utility commission regulation: Performance, determinants, and energy policy impacts. The Quarterly Journal of the IAEE's Energy Economics Education Foundation 3(2): 119-140.

Needleman, S. B. \& Wunsch, C. D. (1970). A general method applicable to the search for similarities in the amino acid sequence of two proteins. Journal of Molecular Biology 48(3): 443-453.

Putnam, R. D. (1976). The comparative study of polítical elites. New York, NY: Pearson Education

Quirk, P. J. (1981). Industry influence in federal regulatory agencies. Princeton University Press.

Schumpeter (2010). Too many chiefs. Inflation in job titles is approaching Weimar levels. The Economist, 24 June 2010. http://www.economist.com/node/16423358.

Studer, M. (2013). Weightedcluster library manual: A practical guide to creating typologies of trajectories in the social sciences with R. LIVES Working Papers 24.

Studer, M. ,Gabadinho, A. ,Muller, N. S. \& Ritschard, G. (2011). An introduction to sequence analysis using the Traminer $\mathrm{R}$ package. Paper presented at Paris Workshop on Trajectories. 
Tepe, M. \& Marcinkiewicz, K. (2013). Career paths of the German administrative elite. A quantitative sequence analysis of administrative state secretaries' biographies. Paper presented at ECPR General Conference.

Trondal, J. ,Murdoch, Z. \& Geys, B. (2015). On Trojan horses and revolving doors: Assessing the autonomy of national officials in the European Commission. European Journal of Political Research 54(2): 249-270.

Vannoni, M. (2015). Explaining the variation in the Europeanization of business: An institutionalist theory. Journal of European Public Policy 22(10): 1-22.

Vogel, D. (1978). Why businessmen distrust their state: The political consciousness of American corporate executives. British Journal of Political Science 8(1): 45-78.

Vogel, D. (1996a). Kindred strangers: The uneasy relationship between politics and business in America. Princeton, NJ: Princeton University Press.

Vogel, D. J. (1996b). The study of business and politics. California Management Review 38(3): 146.

Wilson, G. K. \& Barker, A. (2003). Bureaucrats and politicians in Britain. Governance 16(3): 349-372.

Wonka, A. ,Baumgartner, F. R. ,Mahoney, C. \& Berkhout, J. (2010). Measuring the size and scope of the EU interest group population. European Union Politics 11(3): 463-476.

Yoffie, D. B. \& Bergenstein, S. (1985). Creating political advantage: The rise of the corporate political entrepreneur. California Management Review 28(1): 124.

Zingales, L. (2012). Capitalism for the people: Recapturing the lost genius of American prosperity. New York, NY: Basic Books.

Address for correspondence: Matia Vannoni, School of Public Policy, UCL, The Rubin Building, 29/31 Tavistock Square, London, WC1H 9QU, UK. Email: m.vannoni.12@ucl.ac.uk

\footnotetext{
${ }^{1}$ It should be noted that further differences are identified by the literature. One of them is between direct and indirect employment (Gormley, 1979), such as when we see in-house lobbyists working directly for a firm or private lobbyists working for a PR or public affairs agency under contract by that firm (LaPira and Thomas, 2014). Another difference is between past or future public employment and personal service (Getz, 1993, Hillman et al., 1999). The latter refers to a firm representative serving in a political capacity, such as sitting on a legislative committee, while working for that firm at the same time.

2 The data gathering process was carried out throughout 2014 and 2015.

${ }^{3}$ We use AMADEUS (BvD, 2014) definition of public and private company, which excludes lawyers and social enterprises, for instance, and we check therein whether they are still economically active.

${ }^{4}$ Each company in the EU Transparency Register needs to provide details on the 'Person in charge of EU relations' and the 2014 DOD's European Public Affairs Directory provides a list of all the individuals in charge of in-house EU public affairs.

${ }^{5}$ LinkedIn and other professional social networks have been increasingly used for research purposes over the past few years (Barron, 2011; LaPira and Thomas, 2014). The use of professional social networks throws up some validity issues. For instance, during the past few decades there has been an increase in the use of grand and authoritative job titles on LinkedIn, which in reality are not as significant (Schumpeter, 2010). Nonetheless, in this work we are only interested in where the managers have worked and not in their positions. Furthermore, the validity of self-reported information on LinkedIn is arguably higher than in surveys, the use of which has been common practice so far in this field. Indeed, information on LinkedIn is subject to the scrutiny of hundreds of individuals who personally and/or professionally know the manager.

${ }^{6} \mathrm{We}$ follow the instructions and sample scripts in these works to run the analysis in R.

${ }^{7}$ Table 1 in the online appendix reports the frequencies on which Figure 1 relies.

${ }^{8}$ The R squared for this clustering is 0.64 .
} 
9 The concept sliding doors refers to the strong division between managers' careers and between public and private careers in Brussels. In the EU, present career choices restrain the range of future career opportunities instead of widening it, in contrast to the revolving doors in the US. 